\title{
The Protective Effects of Syzygium aromaticum Essential Oil Extract against Methotrexate Induced Hepatic and Renal Toxicity in Rats
}

\author{
Duaa Abd Al-azem*, Karim H. Al-Derawi and Sahar A.A. Malik Al-Saadi \\ Department of Biology, College of Science, University of Basrah, Basrah, Iraq.
}

\begin{abstract}
The essential oils were isolated from dried Syzygium aromaticum L. seeds by Cleavenger aperture extraction, and fractions were identified by gas chromatography-mass spectrometry (GC-MS). 53 components were detected in Syzygium aromaticum. The components were mainly 21 sesquiterpenes (39.62 \%), eight monoterpenes (15.09\%), onediterpene (1.88\%). The leading components specific in the essential oil was eugenol (64.74\%), caryophyllene (14.36\%), 3-Allyl-6-methoxyphenyl acetate (13.28\%) and 1,4,7, Cycloundecatriene, 1,5,9,9-tetramethy (2.55\%). Biochemically, Results found that the rats treated with (MTX) revealed a significant increase in AST, ALT and ALP levels in compare with controls. Clove essential oil recorded a significant decrease in AST, while, there was a decrease in all enzymes levels in serum of rats related to (MTX) and clove essential oil groups in comparison with control group. The results showed that the administration of clove essential oil significantly decreased elevate levels of ALT, AST and ALP. On the other hand, Histological examination of liver sections of rats treated with (MTX) showed several changes included infiltration of inflammatory cells, congestion, hyperplasia, cytoplasmic vacuolation, degeneration and necrosis. The results showed a normal liver structure in rats that treated with (MTX) and clove essential oil. Rats treated to (MTX) showed sever histopathological changes in the kidney tissues such as necrosis, hemorrhage, degeneration and inflammatory cells. While, in rats treated with (MTX) and essential clove oil a few changes in the kidney tissues were observed.
\end{abstract}

Keywords: Methorexate, Syzygium aromaticum, clove oil, eugenol, GC-MS. Histological.

\footnotetext{
*Correspondence: karimhalderawi59@gmail.com.

(Received: 08 December 2018; accepted: 10 January 2019)

Citation: Duaa Abd Al-azem, Karim H. Al-Derawi and Sahar A.A. Malik Al-Saadi, The Protective Effects of Syzygium aromaticum Essential Oil Extract against Methotrexate Induced Hepatic and Renal Toxicity in Rats, J Pure Appl Microbiol., 2019; 13(1):505-515 doi: 10.22207/JPAM.13.1.57

(c) The Author(s) 2019. Open Access. This article is distributed under the terms of the Creative Commons Attribution 4.0 International License which permits unrestricted use, sharing, distribution, and reproduction in any medium, provided you give appropriate credit to the original author(s) and the source, provide a link to the Creative Commons license, and indicate if changes were made.
} 


\section{INTRODUCTION}

Methotrexate (MTX) is a folic acid antagonist has been widely used to treat cancer patients with cancer specially all undergo chemotherapy as it considered to be a cytotoxic agent ${ }^{1}$. In addition, MTX is mainly used as an antitumor agent for childhood, all treatment and in rheumatoid arthritis patients ${ }^{2}$. Furthermore, MTX used treat inflammation and various autoimmune diseases such as juvenile idiopathic arthritis, rheumatoid arthritis and psoriasis ${ }^{3,4}$. Another side, MTX has many undesirable effects including liver, kidney and gut tissues of laboratory treated with $\mathrm{MTX}^{5}$. In several studies, the damage caused by MTX is listed in many studies, it cause germ cell depletion, loss of spermatozoa as well as distrusting the seminiferous tubules of the testes, decreased sperm count, and sperm DNA damage post treated ${ }^{6}$. In order to reduce the harmful side effects of MTX many researcher focused on isolating botanical compounds to reduce these effects. Syzygium aromaticum L. found normally in tropical areas, specially tropical America and Australia, and it is cultivated in the India, islands of Tanzania, Madagascar, Indonesia, Comoros Islands, Sri Lanka and the south of China ${ }^{7}$. The clove tree is an ever green that grows to a heightend ranging from $10-20 \mathrm{~m}$, possess stems up to $80 \mathrm{~cm}$ long and large, entire, opposite leaves up to $30 \mathrm{~cm}$ wide, flowers and many groups of terminal clusters. The color change starts with the flower buds as they become green gradually until they turn into dark brown or dusty red, the fruit is a drupaceous dehiscent capsule ${ }^{8}$. The essential oil obtained by the dried flower buds of clove has been used since ancient times in traditional medicine, commonly used for flavoring pastry, special sauces and condiments. Moreover, several parts of the plant such as leaves and buds are used in cooking, food processing, pharmacy, perfumery and cosmetics ${ }^{9}$. Syzygium aromaticum has been some components are useful in bacterial and fungal infections $\mathrm{s}^{10-12}$. Preliminary studies suggest that clove oil importance in a chemopreventive role, relevant in cases of lung, skin and digestive cancers ${ }^{13}$ to clarify the most essential oil from Syzygium aromaticum and to evaluate its protective role on rats with (MTX) induced toxicity. The aim of this study is to identify with components of the essential oil from Syzygium aromaticum to evaluate its protective role on rats with (MTX) induced toxicity.

\section{MATERIALS AND METHODS \\ Plant material}

This research was carried out at the University of Basrah, College of Science, Department of Biology, Iraq. The GC-MS Chromatography carried at the University of Basrah, College of Agriculture, Iraq. The fresh buds of clove were collected from Basrah, Iraq were directly used for oil extraction.

\section{Preparation of samples}

One hundred gram of the sample was ground a grinder for 20 second. The small pieces were homogenized for $3 \mathrm{~min}$ to 40 -mesh size. The air-dried sample of clove were pulverized to get the powdered form.

\section{Essential oils Extraction}

Essential oils were separated from water distillation for $4 \mathrm{~h}$ at $100^{\circ} \mathrm{C}$ by using a Clevengertype apparatus. The essential oil was collected in sealed container to prevent any evaporation. Furthermore, the collected oil was dried by anhydrous sodium sulphate and stored in dark glass contain for analysis.

\section{GC-MS analysis}

The oil quality was assessed through analysis by combined gas chromatography and mass spectrometry. GC-MS analysis was carried out using an Shimadzu GC-QP 2010 Ultra gas chromatograph, The temperature of the $\mathrm{GC}$ oven set from $40^{\circ} \mathrm{C}$ to $250^{\circ} \mathrm{C}$ at a rate of $4.3^{\circ} \mathrm{C} / \mathrm{min}$. Helium was used as carrier gas; inlet pressure was $100.0 \mathrm{kPa}$; linear velocity was $48.1 \mathrm{~cm} /$ sec. Column flow was $1.78 \mathrm{~mL} / \mathrm{min}$, Injector temperature: $250^{\circ} \mathrm{C}$; injection mode: split. MS scan conditions: source temperature, $200^{\circ} \mathrm{C}$; interface temperature, $250^{\circ} \mathrm{C}$; Detector Gain, $0.70 \mathrm{kV}+0.10$ $\mathrm{kV}$; Scan speed, 1666. Start $50 \mathrm{~m} / \mathrm{z}$, End $800 \mathrm{~m} / \mathrm{z}$. The relative percentage of the crude essential oil components was expressed as percentage by peak area normalization.

\section{Identification of essential oil compounds}

The essential oil compounds were identified according to retention period and the location of extracted oil in compare with a standard compound, were we compare the spectra of the essential oils compounds with the spectra of a known one from the NIST library 
(2005).

\section{Experimental Design}

Experimental design were approved by College of Science/ Basrah University. Thirty adult healthy rats were divided into three groups randomly as follow:treatment.

Group I : Healthy rats $(n=10)$ no

Group 2 : Treated with MTX ( intraperitoneal injection, $0.125 \mathrm{mg} / \mathrm{kg})(\mathrm{n}=10)$.

Group 3: Treated with (Clove + MTX) ( $\mathrm{n}=10$ ) oral administration, $500 \mathrm{mg} / \mathrm{kg}$ one daily for 7 days, followed by MTX (intraperitoneal injection, $20 \mathrm{mg} / \mathrm{kg}$ ) on day 3 continuously administered for 3 successive days. At the end of experiment, rats were subjected to blood collection under anesthesia by ether inhalation, the blood collected directly from the heart, centrifuged and serum separated which stored at $-20^{\circ} \mathrm{C}$ for biochemical analysis.

\section{Biochemical analysis}

The blood sample was collected from all the experimental rats in a disodium EDTA tubes. The samples were centrifuged at $3000 \mathrm{rpm}$ for 20 min. The plasma was separated and immediately processed for biochemical estimations. The plasma sample was subjected to analysis of biochemical parameters such as aspartate aminotransferase (AST), alanine aminotransferase (ALT), alkaline phosphatase (ALP), estimation using commercial biochemical kits and Reflotron, Plus machine by Roche, USA.

\section{Histopathological examination}

After scarification the liver and kidney tissue were excised by thoracic section, the liver and kidney pieces were excised quickly, and fixed within $10 \%$ neutral formalin for 24 hours. Then, routine histological examination were done, and histological sections were stained with Hematoxylin and Eosin stains and examined by Olympus $\mathrm{CH}-2$ light microscope.

\section{Statistical analysis}

The data was reported as mean \pm SD. analysis of variance (ANOVA) followed by multiple comparisons using SPSS test to compare all groups against control. Results were considered statistically significant at $p<0.05$.

\section{RESULTS AND DISCUSSION}

Essential oil of clove is a colorless or light yellowish fluid extract from dried flower buds by steam distillation. The oils were analyzed by GC-MS and the qualitative and quantitative compositions are presented in (Table 1). The results obtained by $\mathrm{GC} / \mathrm{MS}$ analysis showed that clove essential oil contains 53 components. It is showed the major components in whole clove bud oil contains eugenol (64.74\%), caryophyllene (14.36\%), eugenyl acetate (13.28\%) and 1,4,7 -Cycloundecatriene, 1,5,9,9-tetramethy (2.55 $\%)$, this essential oil represents ten compound monoterpenes $(18.86 \%), 21$ compound sesquiterpenes (39.62\%) and one compound diterpene was (1.88\%) (Figure 1; Table 1).

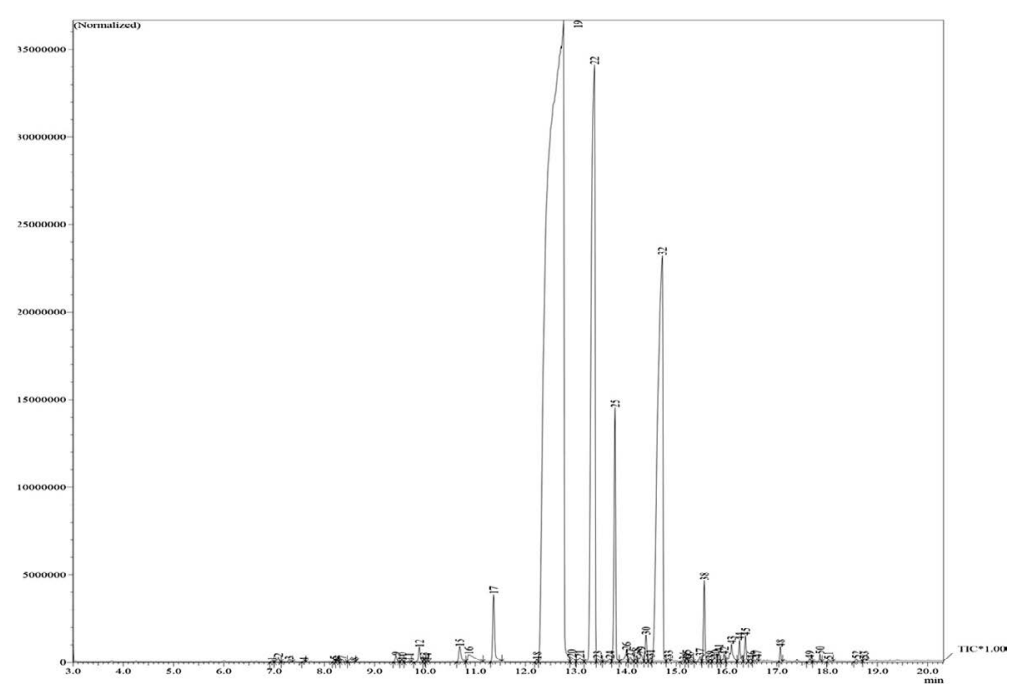

Fig. 1. A typical gas chromatogram of the constituents of essential clove oil. 
Table 1. Compounds identified in the essential oil of Syzygiumaromaticum seeds using gas chromatography mass spectrometry (GC-MS).

\begin{tabular}{|c|c|c|c|c|}
\hline Peak & Component & Formula & $\begin{array}{l}\text { Retention } \\
\text { time }\end{array}$ & $\begin{array}{c}\text { Content } \\
\text { (\%) }\end{array}$ \\
\hline 1 & m-Cymene & $\mathrm{C}_{10} \mathrm{H}_{14}$ & 6.955 & 0.01 \\
\hline 2 & Eucalyptol & $\mathrm{C}_{10} \mathrm{H}_{18} \mathrm{O}$ & 7.084 & 0.05 \\
\hline 3 & 2-Heptanol, acetate & $\mathrm{C}_{9} \mathrm{H}_{18} \mathrm{O}_{2}$ & 7.298 & 0.02 \\
\hline 4 & $\begin{array}{l}\text { 1,4-Cyclohexadiene, 1-methyl-4- } \\
\text { (1-methylel) }\end{array}$ & & 7.592 & 0.01 \\
\hline 5 & Unknown & & 8.200 & 0.02 \\
\hline 6 & $\begin{array}{l}\text { 1-(2-d-Benzoyl-3,5-di-O-toluyl- } \\
\text { beta-d-ribofuranosyl }\end{array}$ & $\mathrm{C}_{37} \mathrm{H}_{34} \mathrm{~N}_{2} \mathrm{O}_{7}$ & 8.250 & 0.01 \\
\hline 7 & 1,6-Octadien-3-ol, 3,7-dimethyl- & $\mathrm{C}_{10} \mathrm{H}_{18} \mathrm{O}$ & 8.353 & 0.03 \\
\hline 8 & Neryl nitrile & $\mathrm{C}_{10} \mathrm{H}_{15} \mathrm{~N}$ & 8.594 & 0.01 \\
\hline 9 & Unknown & & 9.423 & 0.07 \\
\hline 10 & Benzoic acid, ethyl ester & $\mathrm{C}_{9} \mathrm{H}_{10} \mathrm{O}_{2}$ & 9.542 & 0.02 \\
\hline 11 & $\begin{array}{l}\text { 3-Cyclohexen-1-ol, 4-methyl-1- } \\
\text { (1-methylethl) }\end{array}$ & $\mathrm{C}_{10} \mathrm{H}_{18} \mathrm{O}$ & 9.685 & 0.01 \\
\hline 12 & Methyl salicylate & $\mathrm{C}_{8} \mathrm{H}_{8} \mathrm{O}_{3}$ & 9.890 & 0.16 \\
\hline 13 & Benzene, 1-methoxy-4-(1-propenyl)- & $\mathrm{C}_{10}^{8} \mathrm{H}_{12}^{8} \mathrm{O}$ & 9.988 & 0.02 \\
\hline 14 & Unknown & - & 10.042 & 0.01 \\
\hline 15 & Propanal, 2-methyl-3-phenyl- & $\mathrm{C}_{10} \mathrm{H}_{12} \mathrm{O}$ & 10.691 & 0.21 \\
\hline 16 & Phenol, 4-(2-propenyl)-, acetate & $\mathrm{C}_{11} \mathrm{H}_{12} \mathrm{O}_{2}$ & 10.872 & 0.31 \\
\hline 17 & p-Propenylanisole & $\mathrm{C}_{10} \mathrm{H}_{12} \mathrm{O}^{2}$ & 11.366 & 0.81 \\
\hline 18 & Alpha-Cubebene & $\mathrm{C}_{15} \mathrm{H}_{24}$ & 12.230 & 0.03 \\
\hline 19 & Eugenol & $\mathrm{C}_{10} \mathrm{H} 12 \mathrm{O} 2$ & 12.755 & 64.74 \\
\hline 20 & $\begin{array}{l}\text { Cyclohexane, 1-ethenyl-1-methyl-2,4-bis } \\
\text { (1-methylethenyl) }\end{array}$ & $\mathrm{C}_{15} \mathrm{H}_{24}$ & 12.917 & 0.10 \\
\hline 21 & Benzene, 1,2-dimethoxy-4-(2-propenyl) & $\mathrm{C}_{11} \mathrm{H}_{14} \mathrm{O}_{2}$ & 13.080 & 0.09 \\
\hline 22 & Caryophyllene & $\mathrm{C}_{15} \mathrm{H}_{24}$ & 13.372 & 14.36 \\
\hline 23 & $\begin{array}{l}\text { Naphthalene, 1,2,3,4,4a,5,6,8a-octahydro- } \\
\text { 7-methyl- 4- methylene-1-(1- methylethyl) }\end{array}$ & $\mathrm{C}_{15} \mathrm{H}_{24}$ & 13.433 & 0.04 \\
\hline 24 & $\begin{array}{l}\text { 3-Oxabicyclo [4.2.0] oct-5-ene, endo-8- } \\
\text { methy-exo-8-(2-propenyl) }\end{array}$ & $\mathrm{C}_{11} \mathrm{H}_{16} \mathrm{O}$ & 13.681 & 0.05 \\
\hline 25 & 1,4,7-Cycloundecatriene, 1,5,9,9-tetramethy & $\mathrm{C}_{15} \mathrm{H}_{24}$ & 13.781 & 2.55 \\
\hline 26 & $\begin{array}{l}\text { Naphthalene, 1,2,3,4,4a,5,6,8a-octahydro- } \\
\text { 7-methylene-1-(1- methylethyl) }\end{array}$ & $\mathrm{C}_{15} \mathrm{H}_{24}$ & 14.009 & 0.17 \\
\hline 27 & $\begin{array}{l}\text { 1,6-Cyclodecadiene, 1-methyl-5-methylene- } \\
\text { 8-(methylethyl) }\end{array}$ & $\mathrm{C}_{15} \mathrm{H}_{24}$ & 14.088 & 0.06 \\
\hline 28 & $\begin{array}{l}\text { Naphthalene, decahydro-4a-methyl-1- } \\
\text { methylene-7-(1-methylethenyl) }\end{array}$ & $\mathrm{C}_{15} \mathrm{H}_{24}$ & 14.201 & 0.06 \\
\hline 29 & $\begin{array}{l}\text { Naphthalene, 1,2,3,4,4a,5,6,8a-octahydro- } \\
\text { 4a, 8-dimethyl-2-(1-methylethenyl) }\end{array}$ & $\mathrm{C}_{15} \mathrm{H}_{24}$ & 14.302 & 0.13 \\
\hline 30 & 1,3,6,10-Dodecatetraene, 3,7,11-trimethyl-, & $\mathrm{C}_{15} \mathrm{H}_{24}$ & 14.398 & 0.26 \\
\hline 31 & Gamma -Elemene & $\mathrm{C}_{15}^{15} \mathrm{H}_{24}^{24}$ & 14.483 & 0.04 \\
\hline 32 & Eugenyl acetate & $\mathrm{C}_{12} \mathrm{H}_{14} \mathrm{O}_{3}$ & 14.721 & 13.28 \\
\hline 33 & $\begin{array}{l}\text { Naphthalene, 1,2,3,4,4a,7-hexahydro-1, } \\
\text { 6-dimethyl-4-(1-methylethyl) }\end{array}$ & $\mathrm{C}_{15} \mathrm{H}_{24}$ & 14.845 & 0.03 \\
\hline 34 & 2-Oxatricyclo $[4 \cdot 3 \cdot 1 \cdot 0(3,8)]$ decane & $\mathrm{C}_{9} \mathrm{H}_{14} \mathrm{O}$ & 15.142 & 0.02 \\
\hline 35 & $\begin{array}{l}\text { Acetic acid, 4a-methyl-octahydro-1- } \\
\text { oxacyclopropal[d] naphthalene-7-yl ester }\end{array}$ & $\mathrm{C}_{13} \mathrm{H}_{20} \mathrm{O}_{3}$ & 15.209 & 0.04 \\
\hline 36 & 1,6,10-Dodecatrien-3-ol, 3,7,11-trimethyl- & $\mathrm{C}_{15} \mathrm{H}_{26} \mathrm{O}$ & 15.267 & 0.02 \\
\hline
\end{tabular}


Table 1. Continues

\begin{tabular}{|c|c|c|c|c|}
\hline Peak & Component & Formula & $\begin{array}{l}\text { Retention } \\
\text { time }\end{array}$ & $\begin{array}{l}\text { Content } \\
(\%)\end{array}$ \\
\hline 37 & Caryophyllenyl alcohol & $\mathrm{C}_{15} \mathrm{H}_{26} \mathrm{O}$ & 15.473 & 0.06 \\
\hline 38 & Caryophyllene oxide & $\mathrm{C}_{15} \mathrm{H}_{24} \mathrm{O}$ & 15.558 & 0.72 \\
\hline 39 & (+)-Epi-bicyclosesquiphellandrene & $\mathrm{C}_{15} \mathrm{H}_{24}$ & 15.676 & 0.03 \\
\hline 40 & Epiglobulol & $\mathrm{C}_{15} \mathrm{H}_{26} \mathrm{O}$ & 15.775 & 0.07 \\
\hline 41 & $\begin{array}{l}\text { 12-Oxabicyclo [9.1.0] dodeca-3,7-diene, } \\
\text { 1,5,5,8- tetramethyl }\end{array}$ & $\mathrm{C}_{15} \mathrm{H}_{24} \mathrm{O}$ & 15.847 & 0.08 \\
\hline 42 & $\begin{array}{l}\text { 4,8,13-Cyclotetradecatriene-1,3-diol, } \\
\text { 1,5,9- trimethyl-12-(1-methylethyl) }\end{array}$ & $\mathrm{C}_{20} \mathrm{H}_{34} \mathrm{O}_{2}$ & 15.952 & 0.08 \\
\hline 43 & $\begin{array}{l}\text { Tetracyclo }[6 \cdot 3 \cdot 2 \cdot 0(2,5) \cdot 0(1,8)] \text { tridecan } \\
\text {-9-ol,4,4-dimethyl }\end{array}$ & ${ }_{24} \mathrm{O}$ & 16.100 & 0.33 \\
\hline 44 & $\begin{array}{l}\text { Androstan-17-one, 3-ethyl-3-hydroxy-, } \\
\text { (5-alpha) }\end{array}$ & $\mathrm{C}_{21} \mathrm{H}_{34} \mathrm{O}_{2}$ & 16.258 & 0.23 \\
\hline 45 & Aromadendrene oxide-(2) & $\mathrm{C}_{15} \mathrm{H}_{24} \mathrm{O}$ & 16.377 & 0.24 \\
\hline 46 & 2',3',4' Trimethoxyacetophenone & $\mathrm{C}_{11} \mathrm{H}_{14} \mathrm{O}_{4}$ & 16.490 & 0.04 \\
\hline 47 & Curlone & $\mathrm{C}_{15} \mathrm{H}_{22} \mathrm{O}$ & 16.608 & 0.03 \\
\hline 48 & Benzyl Benzoate & $\mathrm{C}_{14} \mathrm{H}_{12} \mathrm{O}_{2}$ & 17.071 & 0.10 \\
\hline 49 & $\begin{array}{l}\text { Benzoic acid, 2-hydroxy-, phenylmethyl } \\
\text { ester }\end{array}$ & $\mathrm{C}_{14} \mathrm{H}_{12} \mathrm{O}_{3}$ & 17.653 & 0.02 \\
\hline 50 & Hexadecanoic acid, methyl ester & $\mathrm{C}_{17} \mathrm{H}_{34} \mathrm{O}_{2}$ & 17.858 & 0.05 \\
\hline 51 & $\mathrm{I}-(+)$-Ascorbic acid 2,6-dihexadecanoate & $\mathrm{C}_{38} \mathrm{H}_{68} \mathrm{O}_{8}^{2}$ & 18.027 & 0.03 \\
\hline 52 & 6-Octadecenoic acid, methyl ester, (Z)- & $\mathrm{C}_{19} \mathrm{H}_{36} \mathrm{O}_{2}$ & 18.583 & 0.03 \\
\hline 53 & cis-9-Hexadecenal & $\mathrm{C}_{16} \mathrm{H}_{30} \mathrm{O}$ & 18.742 & 0.02 \\
\hline
\end{tabular}

\section{Biochemical analysis}

Results found that the rats treated with (MTX) revealed a significant increase in AST, ALT and ALP levels in compare with control (Table 2). $(P<0.05)$ values of ALP, AST and ALT were $61.29 \%$, $60.06 \%$ and $35.50 \%$ respectively in the rats treated with MTX as compared to the controls. Clove essential oil recorded a significant $(p<0.05)$ decreased in AST, while there were decreased in all enzymes concentration in serum of rats related to (MTX) and clove essential oil groups compared

to control rat's treatment (Table 2).

\section{Histological study}

The animals treated with clove essential oil showed no significant changes in histological features of liver (Fig. 2 A-F). While liver sections from (MTX) treated, rats revealed that there were several changes compared to control liver group. These changes included infiltration of inflammatory cells around the central vein, congestion and infiltration cells with the decomposition of hepatic cell edge, hyperplasia in the bile ducts and mitotic

Table 2. Serum levels of live enzymes in experimental groups

\begin{tabular}{cccc}
\hline Treatment & $\begin{array}{c}\text { ALP } \\
\text { (mean } \pm \text { SD) }\end{array}$ & $\begin{array}{c}\text { AST } \\
\text { (mean } \pm S D)\end{array}$ & $\begin{array}{c}\text { ALT } \\
\text { (mean } \pm S D)\end{array}$ \\
\hline $\begin{array}{c}\text { Control } \\
\text { MTX }\end{array}$ & $\pm 15.010^{\mathrm{b}} 41.38$ & $24.09 \pm 18.140^{\mathrm{b}}$ & $29.07 \pm 3.685^{\mathrm{cd}}$ \\
$\pm 37.059^{\mathrm{c}} 61.29$ & $60.06 \pm 2.934^{\mathrm{c}}$ & $35.50 \pm 19.701^{\mathrm{ef}}$ \\
$\begin{array}{c}\text { Syzygiumaromaticum } \\
\text { MTX and }\end{array}$ & $\pm 24.144^{\mathrm{b}} 42.32$ & $17.32 \pm 8.292^{\mathrm{a}}$ & $32.00 \pm 18.295^{\mathrm{d}}$ \\
$\begin{array}{c}\text { Syzygiumaromaticum } \\
\text { R.L.S.D. }\end{array}$ & $33.67 \pm 57.450^{\mathrm{a}}$ & $26.61 \pm 18.344^{\mathrm{b}}$ & $33.59 \pm 13.505^{\text {de }}$ \\
& 6.015 & 5.479 & 6.003 \\
\hline
\end{tabular}

*Values are mean \pm SEM. 
activity with hepatocytes nuclei. Observations indicated to cytoplasm vacuolation, degeneration in endothelial of vessels and bile ducts epithelial. As well as hepatocytes necrosis and nuclei disintegration (Fig. 2 A-F). Alterations in livers of group treated with MTX and clove essential oil was less compared to the livers from rats group treated with (MTX) and including renewing hepatocyte, no signs of inflammation and the tissue more resemble to the normal structure (Fig. 2, G).

Histological examination on liver sections of the group treated with a MTX drug and Syzygium aromaticum volatile oil showed that presence of regenerated hepatocytes, as seems more regular as plates and organized that seems normal and with less inflammatory cells compared to rats treated by drug only (Fig.2, H). Kupffer cells appeared normal but can see thickness of nuclei in some cells compared to rats with induced toxicity (Fig. 2, I).More regular urinary tubules, normal cortex and glomerulus. Results also clarified the changes in kidney sections and showed that renal tissues of the control group had normal structure with no evidence of pathological changes (Fig.3A, B). In the group treated with MTX, kidney tissue showed necrosis in some urinary tubules, renal glomeruli and hemorrhage with the degeneration of Bowman glomerulus (Fig. 3,C), 0.5 $\mathrm{mg} / \mathrm{kg}$ occurred decomposition of urinary tubules decomposition of Bowman's capsule, lobulated glomerulus and haemosidrin deposition (Fig.3, D). The inflammatory response appeared as infiltration
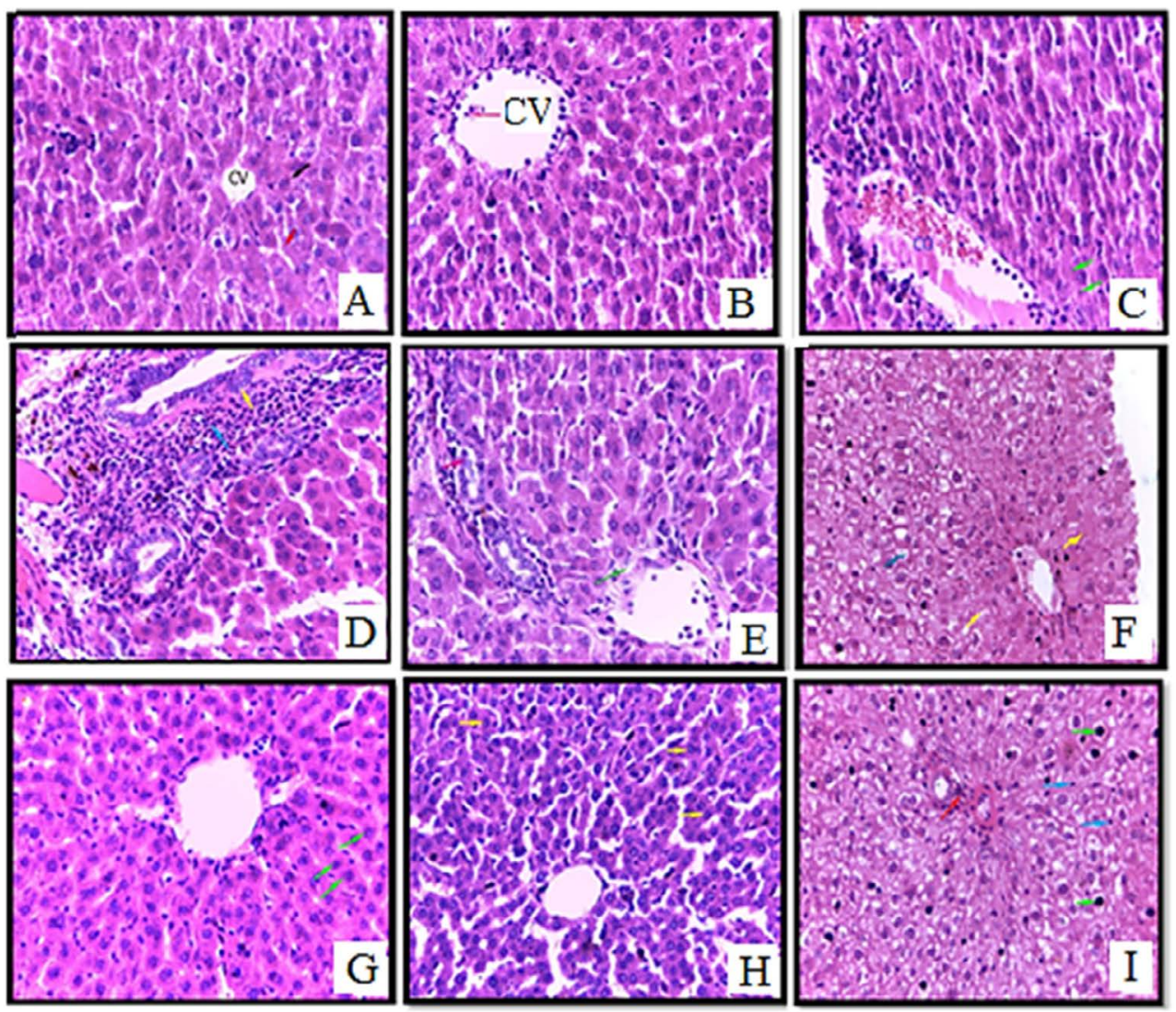

Fig. 2. HE stained liver sections from rats A- Control (showing normal tubular epithelial cell, no necrosis noted) B-D high dose MTX: B- infiltration of inflammatory cells around the central vein: $C$ - congestion and infiltration cells with the decomposition of hepatic cell edge:D- hyperplasia in the bile ducts: $\mathrm{E}$ - vascular cytoplasm of cells, degeneration in endothelial of vessels and bile ducts epithelial: F- hepatocytes necrosis and nuclei disintegration: G-I, group treated with Methotrexate and clove essential oil: G-no presence inflammatory in the liver tissue: $\mathrm{H}$ - presence of renewable hepatocytes: I- Kupffer appeared normal but can see thickness of nuclei . CV in A, B = Central vein (Magnifications, all $470 \mathrm{X}$ ). 
neutrophil, non-cellular material deposition and hemorrhage (Fig.3, E), increase in adipose tissue and necrosis in some proximal tubules (Fig. 3, F). Histological sections of the kidney of animals treated with essential oil for plant illustrate few changes comparing with group treated by MTX, including the cells organized around the normal shape and the absence of inflammatory cells (Fig.3,G,H).Low and high doses of (MTX) caused hepatic and renal toxicities and functions causing
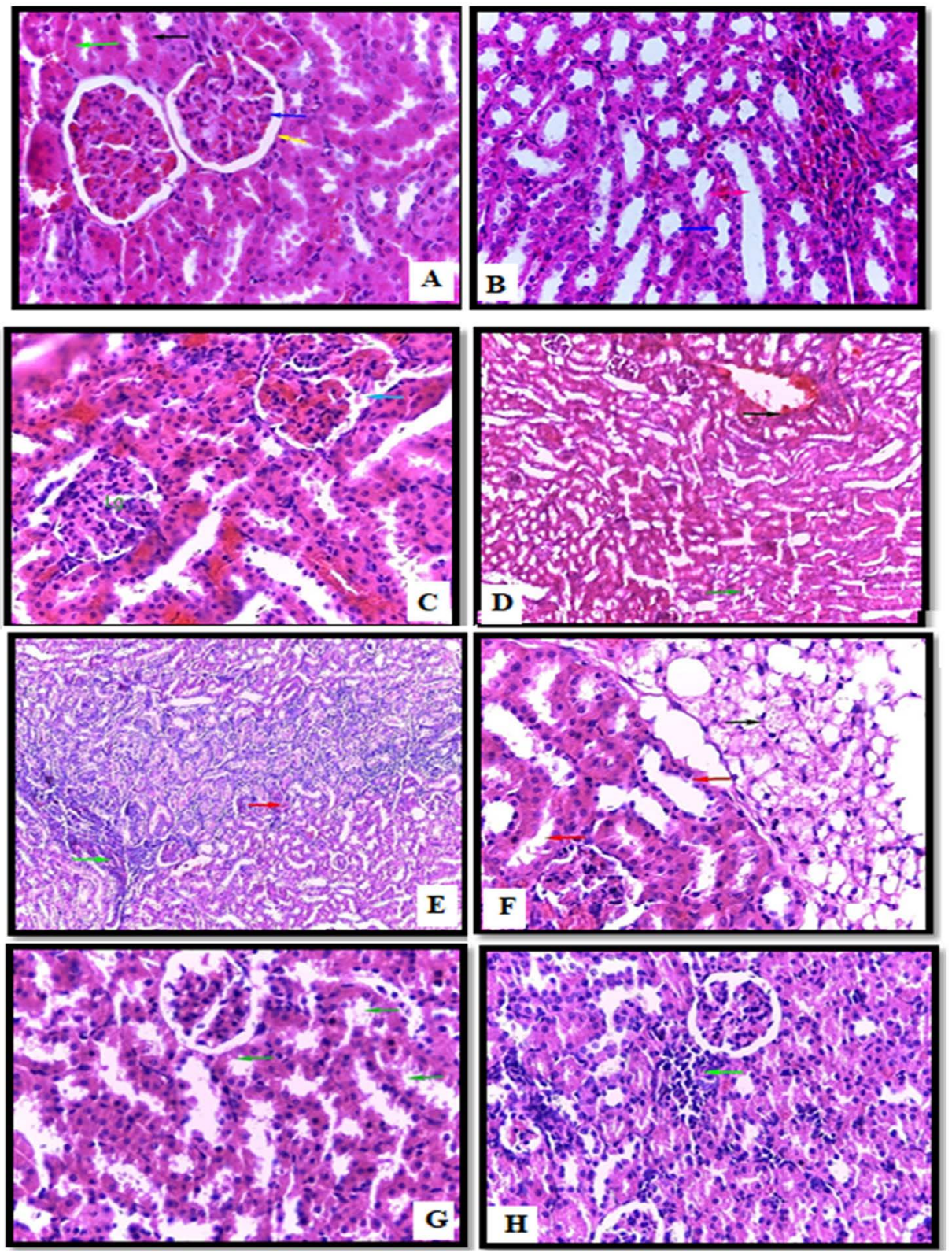

Fig. 3. Photomicrograph of HE stained kidney sections from rats A- B: Controlshowing normal tubular epithelial cell, no necrosis noted; C- necrosis in some tubule urinary, renal glomeruli and bleeding with the degeneration of Bowman glomerulus; D- decomposition of urinary tubules decomposition of Bowman and lobulated glomerulus and Haemosidrin; E- the inflammatory response and hemorrhage; F- increase in adipose tissue and necrosis in some tubule urinary; $\mathrm{G}-\mathrm{H}$ the cells organized around the normal shape and the absence of inflammatory cells. (Magnifications, all $470 \mathrm{X}$ ). 
changes in of rat's visceral organs ${ }^{3,14}$. While, treatment with clove essential oil showed significant protective effect on methotrexate and hence in liver enzymes, this may indicate that the reduction in renal filtration rate can be due to toxic effects of methotrexate in kidney (Table 2). Results proved that prophylactic treated of clove essential oil exhibits protective effects on MTX induced toxicity lead to increased AST, ALT and ALP which considered as hepatotoxicity, impaired liver function and biochemical indicators of liver damage, these findings have been agreed with ${ }^{15,16}$, which reported that MTX is a folic acid antagonist that can cause unpredictable serious side effects. MTX recorded a significant increased $(p<0.05)$ in ALP, ALT and AST, while treatment of MTX with clove essential oil noticed decreased in ALP, ALT and AST enzyme (Table 2). The results, revealed that clove essential oil proved to have a significant level of protection against MTX effects on liver. The high levels of ALT, AST and ALP in MTX-treated rats is associated with the increased damage by MTX ${ }^{17}$. While treated clove essential oil $200+$ MTX group, serum activities of ALT, AST, ALP was decreased; the rats treated with Methotrexate has a toxic effect in liver when it provoked a distinguished increase in ALT and AST activities. Our results suggest that MTX can move the liver and causing abnormal serum levels of liver enzymes that agreed with (18), and using essential oil of cloves with MTX causes protection agent. The significant inhibition of these metabolically active enzymes by MTX is an indication of the generation of free radicals and ROS that further affect the cell pathways. Clove essential oil was possible act as antioxidant phytochemicals that can scavenge the toxic free radicals as well as, the increase of serum levels may be due to the cytotoxic effect of MTX on liver cells, The elevated serum levels are results from cytotoxic effect and the elevated activities of the serum mirror the leakage in permeability of the plasma membrane, and causing the movement of high quantity of these enzyme to blood serum which in turn, is associated with cell death ${ }^{19}$. Almotabagani et al. ${ }^{13}$ showed that binds that MTX to the hydrofolatereductase that lead to the blocking of the synthesis amino acid and nucleic acid, this blockage lead to damage of both organelles and plasma membranes which interfere with their function, allowing enzyme leakage depending upon the degree of hepatic damage. Moreover, methotrexate is also known to cause elevation of hepatic transaminases ${ }^{20}$. Griffith et al. ${ }^{21}$ observed that folate supplementation can reduce the incidence of elevated liver enzymes during MTX treatment it can induce abnormalities in liver function. Moreover, Alexander et al. ${ }^{22}$ indicate the increase of ALP level is correlated with the severity of the toxic effect of MTX and ALT is one of the best indicators of liver necrosis, on the other hand, increase in liver enzyme levels and increased rate of inflammatory cell infiltration in methotrexate treated animals and this may contribute in the development of hepatorenal damage may be due to mitogen-activated protein kinas (MAPK) ${ }^{23,24}$. The current study has found histopathological changes in the liver tissues in rats treated with different doses of extract treatedrats there were congestion, inflammations around central vein, cytoplasmic vacuolations (Hydropic degenerations) in the hepatocytes located towards the periphery of the hepatic lobules around the central veins in higher doses of extract treated rats (around central veins in which their nuclei. Other researchers showed similar including congestion and degenerations in liver cells and necrosis after four weeks from treatment ${ }^{25}$. The disturbance in lipid inclusions and fat metabolism cause the fluid or lipids to accumulate $^{26}$. Swayeh et $a l^{16}$ found that the oxidative tissue damage caused by MTX increase lipid oxidation in both liver and kidney declined level of antioxidant enzymes. MTX-induced toxicity is featured by a significant increase in of proinflammatory cytokines ${ }^{27}$, the induced damage in renal tissue characterized by subsequent neutrophil infiltration and oxidative stress contribute ${ }^{28}$. Many pathological alterations extending to cellular damage occur, in case that the balance between oxidants and anti-oxidants is not preserved in tissues ${ }^{29}$. The mechanisms of MTX proposed to inhibit purine and pyrimidine synthesis and amines accumulation ${ }^{30}$. The renal damage caused by MTX involve two mechanisms, the precipitation of MTX in renal tubules, will induce tubular injury, in addition, MTX induce a transient decrease in glomerular alteration rate after each dose ${ }^{31}$. Many researchers report the plant extract contain chemical component can interred with metabolism process and reported 
the role of certain flavonoids, triterpenoids and steroids in hepatoprotection against hepatotoxins. The presence of these certain compounds in Syzygium aromaticum is the reason of the protective effects of rats liver. Our results showed that the essential oil contains ten compounds, monoterpenes (18.86\%), 21 compound sesquiterpenes (39.62\%) and 1 compound diterpene was (1.88\%) (Fig. 1; Table 1). Our results is in agreement with the precedent studies ${ }^{32}$. Phytochemical studies showed the highest concentration of clove essential oil was of eugenol, eugenyl acetate and $\lambda$-caryophyllene which agreed with previous experiments ${ }^{33}$. The presence of eugenol and caryophyllene within the essential clove oil make it useful in both herbal and modern medicines, because of their antibacterial, antifungal, anti-inflammatory capacities, insecticidal and antioxidant effects. Moreover, they are traditionally used in food industry as flavoring and antimicrobial agent ${ }^{34}$. Regarding Eugenol, which is the main component of clove oil, involves in inner secretory columnar cell layer and desquamation and the exerts adverse effects on secretory activity of seminal vesicle ${ }^{35}$, spermicidal activity on ejaculated human spermatozoa ${ }^{36}$. Also confirmed the antinociceptive activity of eugenol predominantly inhibits the peripheral pain mechanism ${ }^{37}$. Clove oil is traditionally used as atherapeutic agent to treat many symptom such as anti-phlogistic, anti-vomiting, analgesic, antispasmodic, anticarminative, kidney reinforcement, antiseptic, diuretic, odontalgic, stomachic and tonicardiac ${ }^{38}$. Alma et al. ${ }^{32}$ showed that the essential oil of clove contained $87 \%$ eugenol, 8.01 $\%$ eugenyl acetate and $3.56 \% \beta$-Caryophyllene. Hossainet $a l .^{33}$ reported eleven chemical components were identified in the essential oil isolated from, the isolated components representing eugenol $51.51 \%$, caryophyllene $36.20 \%$, $\beta$ - caryophyllene (4.26\%), acetyleugenol $2.64 \%$ and carvacrol $2.42 \%$. Safrudin et al. ${ }^{33}$ reported that clove oil contains eugenol (72.40\%), $\beta$-caryophyllene (12.61\%) and eugenyl acetate (9. $59 \%$. Nassar et $a{ }^{39}$ Identified sixteen volatile compounds, the main components were eugenol (71.56 \%) and eugenol acetate (8.99\%). Clove considered to be are important drug with different applications like antioxidant, antifungal, antiviral, antibacterial, anti-inflammatory, antithrombic, antipyretic, analgesic, anticonvulsant, antimycotic, insecticidal, antimutagenic, antiulcerogenic etc. Eugenol, ethyl acetate and caryophyllene are the major components and it is responsible for the activities above. The area of developing efficacious formulations using clove or eugenol have a great potential ${ }^{7}$. On the other hands, studies with polyphenolic compounds have revealed a potential antioxidants used for the treatment and prevention of oxidative stress ${ }^{40}$.The curative nature of clove extract against MTX toxicity by restore hepatocytes function and prevent the lost of proteins and albumin via the kidney as a results of nephroprotection ${ }^{19}$. Furthermore, the present study showed that clove essential oil administration with MTX results in oxidative stress decrease and free radical mediated tissue injury as a result of its ability to search for free radicals and this is one of the major antioxidant mechanisms to hinder the chain reaction of lipid peroxidation. Furthermore, clove essential oil that revealed anti-oxidant activity and exhibit an inhibitory effect on lipid peroxidation, which cause a decline in the inflammatory response strength.

\section{CONCLUSION}

To summaries, the clove essential oil can be used as a main source of natural eugenol isolation which has an antimicrobial properties. Our data revealed the role of oxidative stress in MTX-induced renal toxicity in rats. Syzygium aromaticum may give protection from damage through the reduction of oxidant products and enhance the antioxidant activity, the modulation of oxidative stress with Syzygium aromaticum could be an effective factor of reducing renal impairment that is caused by MTX therapy. More researches must be conducted to understand how can Syzygium aromaticum prevent renal damage. The protective effects of the essential oil that was seen in the present study may be due to this component. Our results showed that many effects of Syzygium aromaticum on kidney, liver and enzymes. The hepatoprotective effects may be due to the scavenging of anti-oxidants and free radicals, the enzymatic and nonenzymatic antioxidants levels were inhibited in liver and kidney. 


\section{ACKNOWLEDGMENT}

We gratefully acknowledge the all kind of technical supports from the Department of Biology, College of Science, University of Basrah, Basrah, Iraq.

\section{CONFLICT OF INTEREST}

conflict of interest.

The author declares that there are no

\section{REFERENCES}

1. Dalaklioglu S, Gence GE, Aksoy NH, Akcit F, Gumuslu S. Resveratrol ameliorates methotrexate-induced hepatotoxicity in rats via inhibition of lipid peroxidation. HumExpToxicol, 2013; 32: 662-671.

2. Malik F, Ranganathan P. Methotrexate pharmacogenetics in rheumatoid arthritis: a status report. Pharmacogenomics, 2013; 14: 305-314.

3. Funk RS, Van HL, Becker ML and Leeder JS. Low-dose Methotrexate Results in the Selective Accumulation of Aminoimidazole Carboxamide Ribotide in an Erythroblastoid Cell Line, J. PET., 2013; 347(1): 154-63.

4. Schwartzberg LS, Vogel WH, Campen CJ, Methotrexate and Fluorouracil Toxicities: A Collaborative Practice Approach to Prevention and Treatment, The Ascopost, 2014; (7): 234- 236.

5. Ozogul B, Kisaoglu A, Turan MI, Altuner D, Sener $E$, Cetin N, et al. The effect of Mirtazapine on methotrexate - induced toxicity in rat liver. Science Asia, 2013; 39: 356-362.

6. T. Yaman, A. Uyer, M.S Kaya, O. F. Keles, B.A. Uslu and Z. Yener. Protective effects of silymarin on methotrexateinduced damages in rat testes. Braz.J. Pharm. Sci. 2018; 54(1): 3-10

7. Singh J, BaghotiaA andGoel S. Eugenia caryophyllata Thunberg (Family Myrtaceae): A Review. International journal of research in pharmaceutical and biomedical sciences,2012; 3(4):1469-1475.

8. Sharma V, Kumawat TK, Seth R, Sharma A. A review on anti-dermatophytic efficiency of plant essential oils, Int. J. Pure App. Biosci.,2014; 2(6): 265-278.

9. Trajano VN and Lima EO. Inhibitory effect of the essential oil from Eugenia caryophyllata Thumb leaves on coalho cheese contaminating microorganisms. $\mathrm{Ci}$ ךnc. Tecnol. Aliment., Campinas.,2010; 30(4): 10011006.

10. Johnson OO, Ayoola GA and Adenipekun, T. Antimicrobial Activity and the Chemical Composition of the Volatile Oil Blend from Allium sativum(Garlic Clove) and Citrus reticulate (Tangerine Fruit). International Journal of Pharmaceutical Sciences and Drug Research, 2013; 5(4): 187-193.

11. Rodraguez $O$, Sanchez $R$, Verde $M$, Nתoez $M$, Ra os $\mathrm{R}$ and Chavez A.Obtaining the essential oil of Syzygiumaromaticum, identification of eugenol and its effect on Streptococcus mutans. J. Oral Res., 2014; 3(4): 218-224.

12. Hamini-Kadar N, Hamdane F, Boutoutaou R, Kihal M and Henni JE. Antifuncal activity of clove (SyzygiumaromaticumL.) essential oil against phytopathologenic fungi of tomato (SolanumlycopersicumL.) in Algeria. Journal of Experimental Biology and Agricultural Sciences., 2014; 2(5):447-454.

13. AL-MotabaganiMA.Histological and histochemical studies on the effects of mehotrexate on the liver of adult male albino rat, Int. J. Morphol., 2006; 24(3): 417-422.

14. Mohamed M, Hesham AK, Abdelrahman IA, Mohamed AD. and Saleh A. Diosmin Attenuates MethotrxateInduced Hepatic, Renal, and Cardiac Injury: A Biochemical and Histopathological Study in Mice. Oxide Med Cell Longey, 2017; 80:165-80.

15. Rizvi SAS. Evaluation of Cucurbitapepo peel hepatoprotection against $\mathrm{CCl} 4$ induced damage in rat and. antibacterial activities, Ph.D 2012, Quaid-i-Azam University.

16. Swayeh NH, Abu-Raghif AR, Qasim BJ and Sahib HB. The protective effects of Thymus vulgaris aqueous extract against methotrexate-induced hepatic toxicity in rabbits. Int. J. Pharm. Sci. Rev. Res., 2014; 29: 187-93.

17. Helen ST, Schiano TD, Kuan S F, Hanauer SB and Conjeevaram HS. Hepatic effects of long term methotrexate use in the treatment of inflammatory bowel disease. Am. J. Gastroenterol., 2000; 95(11): 3150-56.

18. Khokhar A, Qayyum A and Aslam Khan MW. Protective effect of melatonin against methotrexate induced hepato protective in mice. Pak Armed Forces Med J., 2017; 67(1) : 126-130.

19. Tunali-Akbay T, Sehirli O, Ercan F and Sener G. Resveratrol protects against methotrexate-induced hepatic injury in rats. J. Pharm. Pharmaceut. Sci., 2010; 13(2): 303-310.

20. Diwan SY. Effect of Peganumharmala methanol extract on liver and kidney of mice administered MTX drug. Journal of Al-Nahrain University., 2013; 16(4): 161-166.

21. Griffith SM, Fisher J, Clarke S, Montgomery B, Jones PW, Saklatvala J, et al. Do patients with rheumatoid arthritis established onmethotrexate and folic acid 5 $\mathrm{mg}$ daily need to continue folic acid supplements long term? Rheumatology.,2000; 39(10):1102-1109.

22. Alexander VAD, NAmani S, Subramani P, Sengodan B. and Radhakrishnan A. Ameliorative Effect of Quercetin on Methotrexate-induced Toxicity in SpragueDawleyRats: A Histopathological Study. Indian J. of Pharmaceutical Education and Research., 2016; 50(3): 200-208.

23. El-Sheikh AAK,Morsy MA, Abdalla A M, Hamouda H A and Alhaider, I.A. Mechanisms of thymoquinonehepatorenal protection in methotrexate-induced toxicity in rats._Mediators Inflamm., 2015; (4): 1-12.

24. Kalemci S, Topal Y, Celik SY, Yilmaz N, Beydilli $\mathrm{H}$ and Kosar MI. Silibinin attenuates methotrexate-induced pulmonary injury by targeting oxidative stress. ExpTher Med., 2015; 10(2):503-507.

25. Bhakti AM and Thankamani M. Protective effect of MorinaCitrifolia L.( fruit extract) on methotrexateinduced toxicities - hematological and biochemical studies., 2016; 1: 1-7. 
26. Patel N N, Ghodasara D J, Pandey S, Ghodasara PD, Khorajiya JH, Joshi BH, et al. Subacutetoxicopathological studies of methotrexate in wistar rats. Vet World, 2014; 7: 489- 495.

27. Ebaid H, Dkhil M, Danfour M, Tohamy A and Gabry M. Piroxicam-induced Hepatic and Renal Histopathological Changes in Mice. Libyan Journal of Medicine, 2007; 2: 1-13.

28. Uzar E, Koyuncuoglu HR, Uz E, Yilmaz HR, Kutluhan $\mathrm{S}$, and Kilbas $\mathrm{S}$. The activities of antioxidant enzymes and the level of malondialdehyde in cerebellum of rats subjected to methotrexate: protective effect of acidphenethyl ester. Molecular and cellular biochemistry., 2006; 291(1-2):63-8.

29. Kolli VK, Abraham P, Isaac B and Selvakumar D. Neutrophil infiltration and oxidative stress may play a critical role in methotrexate-induced renal damage. Chemotherapy., 2009; 55(2):83-90.

30. Ehab T, Zaki TZ, Walid A and Hamada H. Methotrexateinduced Hepatic and Renal Toxicity: Role of $L$ - Carnitin in Treatment., 2014; 2(4): 85-92.

31. Alwachi SN and Alsaadi YI. Effect of methotrexate on the liver enzymes and lipid profile in adult female albino mice. Baghdad Science Journal, 2013; 10(1) : 176-181.

32. Alma AH, Ertas $S$, Kollmannsberger H. Chemical composition and content of essential oil from the bud of cultivated Turkish clove(Syzygiumaromaticum L.). Bio. Resources., 2007; 2(2): 265-269.

33. Hossain MA, Al-Hashmi R A, Weli AM, Al-Riyami, Q and Al-Sabahib, G. N. Constituents of the essential oil from different brands of SyzigiumcaryophyllatumL. by gas chromatography-mass spectrometry. Asian Pacific
Journal of Tropical Biomedicine., 2012; 1446-1449.

34. Safrudin I, Maimulyanti A, and Prihadi A. Effect of crushing of clove bud (Syzygiumaromaticum)and distillation rate on main constituents of theessential oil. American Journal of essential oils and natural products., 2015; 2(3): 12-15.

35. Niwano $Y$, Saito $K$, Yoshizaki F, Kohno $M$ and Ozawa T. Extensive screening for herbal extracts with potent antioxidant properties. J. Clin. Biochem. Nutr., 2011; 48(1): 78-84.

36. Kumari VG, Sampatharaj $R$, Selvaraj $M$ and Thangamani R. Effect of short-term treatment of eugenol on seminal vesicle of adult albino rats. Indian J. Exp. Biol., 1998; 36:1240-4.

37. KadamSS andJyotsna W. Identification of major volatile (essential oil) constituents of "carrom seeds" and "clove buds". International Journal of scientific research and reviews, 2014; 3(2): $85-94$.

38. Mohammed $\mathrm{N} \mathrm{H}$, Ahmed $\mathrm{MH}$ and Hussien 1 MO. Qualitative analysis of the essential oil of Syzygiumaromaticum (L.) (Clove) using gas chromatography -mass spectrometry (GC-MS). International Journal of research in pharmacy chemistry, 2015; 5(2): 350-354.

39. Nassar M, Gaara AH, El-Ghorab AH, Farrag A, Shen $H$, Huq $E$ and Mabry TJ. Chemical constituents of clove (Syzygiumaromaticum, Fam. Myrtaceae) and their antioxidant activity. Rev. Latinoamer. Quam., 2007; 35(3): 47-57.

40. Uyar A, Yener Z and Dogan A. Protective effects of Urticadioica seed extract in aflatoxicosis: histopathological and biochemical findings. Brit Poultry Sci., 2016; 57(2): 235-245. 